\title{
Molecular sovereignties: patients, genomes, and the enduring biocoloniality of intellectual property
}

\author{
Eva Hilberg ${ }^{1}$ (1)
}

Accepted: 16 June 2021 / Published online: 3 July 2021

(C) The Author(s), under exclusive licence to Springer Nature Limited 2021

\begin{abstract}
Monoclonal antibodies are revolutionizing cancer treatments, but come at an increasingly problematic price for health services worldwide. This leads to pressing demands for access, as in the case of Kadcyla. In 2015, patients in the United Kingdom invoked the sovereign rights of the Crown in order to demand access to this expensive yet potentially life-saving medicine that had prior been delisted due to price. This article interprets this campaign as an act of sovereign reassertion against a fundamental exclusion, which, however, ultimately fails to challenge the concrete mechanism enabling this exclusion-intellectual property (IP). By connecting this example to other declarations of molecular sovereignty, the article argues that the use of sovereignty can perpetuate further exclusion. Drawing on the notion of biocoloniality (Schwartz-Marín and Restrepo 2013) it points out that the intellectual property regime contains a deeply embedded fiction of the world as terra nullius, a blank uninhabited canvas ripe for discovery and appropriation. This decontextualised vision of life as property works to exclude populations and patients from playing a significant role in determining the use of technologies and treatments. Instead of countering this fundamental exclusion, the concept of sovereignty further entrenches this assumption and merely contests the assignation of this property.
\end{abstract}

Keywords Biocoloniality · Intellectual property $\cdot$ Monoclonal antibodies · Sovereignty $\cdot$ Access and benefit sharing agreements

Eva Hilberg

e.hilberg@sheffield.ac.uk

1 Faculty of Sociological Studies, ICOSS, University of Sheffield, 219 Portabello, Sheffield S1 4DP, UK 


\section{Introduction}

A new generation of extremely costly medicines poses a profound challenge to health systems around the world, confronting national health systems with a powerful global industry made up of a small number of influential players. As national systems seek to determine what price they can afford, patients demand access to both these treatments and to the debate on prices, using a variety of strategies ranging from signature campaigns to specific legal challenges. In 2015, patients in the United Kingdom (UK) and an international coalition of non-governmental organisations (NGOs) invoked the rights of the sovereign in order to demand access to Kadcyla, an expensive yet potentially life-saving medicine. In 2018, this strategy was used once again for access to Orkambi, a cystic fibrosis treatment. These campaigns are only the most recent part of a longer history pitting a globalised biotech industry against national governments, national health services, patients and populations, such as for example indigenous groups. This struggle often relies on claims to sovereignty, used to counter the power of an industry that routinely operates across national boundaries. This article takes these emancipatory claims seriously, understanding them as performances of sovereignty rather than merely representing a strategic choice. But what do patients and populations declare when they declare sovereignty?

This article sets out several examples of sovereignty campaigns in the field of molecular medicine and technology, and analyses their effects. In the case of Kadcyla, patients in the UK invoked Crown use, the right of the sovereign monarch, in order to demand access to an expensive potentially life-saving medicine, Kadcyla (ado-trastuzumab emtansine or T-DM1), a monoclonal antibody treatment for human epidermal growth factor receptor 2 (HER2)-positive metastatic breast cancer (The Coalition for Affordable T-DM1 2015). This legal strategy demanding Crown use was repeated in the case of Orkambi, which treats cystic fibrosis "in patients from two-year-olds to adults, who have a specific genetic mutation known as F508del" (BBC News 2019). These very targeted sovereignty campaigns are then connected to broader demands for genomic sovereignty in low- and middle-income countries such as Mexico and Colombia, and especially within the debate about access and benefit sharing around the Convention on Biodiversity (CBD).

By connecting these two different types of campaigns for access, this article draws attention to continuities between these performances of molecular sovereignty, placing them in a longer history of struggle against a globalised biotech industry. Here, patients groups, indigenous populations, and other 'affective communities' (Hutchison 2016) have formed around experiences of exclusion by and from modern biomedicine. In this reading, the Kadcyla case thus becomes part of a larger pattern of challenges to the exclusionary practices at the foundation of the global biomedical sector. Comparisons between different campaigns however can be used to draw attention to the structural effects inherent in the notion of sovereignty, which on the one hand seeks to establish an unfettered right, but on the other also imports a position of exclusivity-based on the notion of property. 
The otherwise often overlooked influence of intellectual property connects these otherwise different cases, enabling the industry to set prices and thus determine access to treatments. Drawing on the concept of biocoloniality (Schwartz-Marín and Restrepo 2013), the article argues that intellectual property's colonial era legacy contains an understanding of biodiversity and life as a uninhabited blank canvas ready for discovery and appropriation. In asserting authority over unique molecular attributes or conditions, current struggles unwittingly (re)-inscribe this particular version of sovereignty. This imports a vision of exclusive property rather than shared or communal goods, and fails to engage with complex issues such as price. From this perspective, the drawing of boundaries imposes new exclusions and further embeds the intellectual property regime's inbuilt exclusion of patients and peoples as the disregarded inhabitants of the terra nullius of molecular life.

\section{Sovereign patients—a performative reading}

On 1st October 2015, the Coalition for Affordable T-DM1 (hereafter: 'the Coalition') issued a letter to the then Secretary of State for Health Jeremy Hunt, demanding that the UK government issued a compulsory license on a life-extending cancer medicine trastuzumab emtansine, trade name: Kadcyla (The Coalition for Affordable T-DM1 2015). The Coalition's challenge addressed the problem of the prohibitive cost of Kadcyla by seeking to override the industry's unfettered monopolistic prerogative-relying primarily on the instrument of Crown use provisions of Sect. 55 of the UK Patents Act 1977. The UK National Institute for Health and Care Excellence (NICE) and the UK Cancer Drug Fund had previously declared this treatment unaffordable at $£ 5908$ for a 3 -week cycle, or $£ 90,000$ for a standard 14 months cycle of treatment (Triggle 2014). ${ }^{1}$ Kadcyla is "a next generation breast cancer drug", combining a cancer-killing cytotoxic agent with a monoclonal antibody, trastuzumab (Staines 2017). This treatment has given hope to many, but in 2016 it was also "the most expensive breast cancer drug ever sold" (Boseley 2016).

This somewhat paradoxical situation, potentially pitting the sovereign of the UK against British health agencies, raises the question of the implications of this action beyond the immediate legal context: why did patients invoke this particular passage of law? Was this only an opportune strategic choice? This article provides a performative reading of rights activism, which foregrounds patients' desire to be recognised as subjects that count in the delivery of healthcare, and are using this particular method to wield power in a process that usually excludes them entirely. The rights of the Crown are here effectively turned into somatic rights, which are claimed by 'active' patients — or biological citizens (Heath, Rapp, and Taussig 2004; Rose 2007). Furthermore, the choice of this particular legal strategy highlights the absence of any other avenues of challenge to the monopolistic position of the

\footnotetext{
1 Roche disputed this figure but did not disclose financial details. A newspaper article at the time reports: "The original price, however, was $£ 5,900$ a month and patients tended to be on it for an average of 9.6 months, it said, bringing the real cost to the NHS down to about $£ 60,000 "$ (Boseley 2015b).
} 
pharmaceutical industry created by the IP regime. In this context, the Coalition's demand represents a clear declaration of sovereignty in the face of exclusion, reasserting power in a field in which patients are usually entirely absent. It mobilises the conceptually unfettered rights of a sovereign, utilizing a very specific limited exception to the IP rights regime. This strategy provides a glimpse of the potential power of patients' demands, but its necessarily limited remit does not seek to address the inbuilt absence of patients for instance within deliberations of price. Their absence in the IP regime has a deeper historic background and fundamental conceptual roots, as shown below.

The exclusion of patients from decisions affecting their lives and health is profound. The Coalition pointed out that de-listing Kadcyla would effectively make this medicine unavailable for patients in England, which would result in patients with HER2positive, metastatic breast cancer dying earlier than necessary. In particular cases this could lead to quite a significantly lessened life span, on average however amount to approximately six months of life (Boseley 2015a). In the face of these devastating consequences, the Coalition's demand relied on a particular passage in British Patent Law: the Rights of the Crown. The Crown, as the sovereign ruler of Great Britain, retains power to override existing patents and intellectual property rights (IPRs) in cases of pressing need, such as for example "foreign defence purposes", medicines and research (Yang 2015, p. 416). ${ }^{2}$ These rights apply especially to any areas of the state that are part of the "services of the Crown", which originally covered "the civil and armed services and the Post Office" (Boehm and Silberston 1967, p. 120). In 1965, a landmark case on access to the antibiotic tetracycline confirmed "the treatment of patients in hospitals" as falling within the remit "of the functions of government", but also pointed out that it only applied to patients as long as they were supplied by the hospital, not while they are receiving medication through a general practitioner or pharmacist (Ibid.; "Pfizer Corporation v. Ministry of Health" 1965). From its inception, Crown use thus referred to the needs of services provided by the Crown, not the needs of patients as recipients of this service. Since then, Crown use has been invoked in a very small number of cases. The Coalition argued that de-registering Kadcyla constituted a need for such a declarationdespite this emergency being co-produced by the British health agencies themselves.

A separate signature campaign for access to Kadcyla conducted by another group of breast cancer campaigners heightened public pressure further, delivering 42,000 signatures to Roche Pharmaceuticals on 28th October 2015 (Breast Cancer Now 2015). In response to these challenges, Roche decided to drop Kadcyla's price to an undisclosed amount, to make it more affordable for the UK Cancer Drugs Fund (Boseley 2015b). While this made the drug available in England at least for the moment, even Roche's offered discount "was not enough to bring the price within the NICE upper threshold of $£ 50,000$ " thus causing a "post-code lottery" of access

\footnotetext{
2 These rights under Sect. 55 of the UK Patents Act are geared at "(a) the supply of anything for foreign defense purposes, (b) the production or supply of specified drugs and medicines, and (c) such purposes relating to the production or use of atomic energy or research into matters connected therewith" (Yang 2015, 406).
} 
(Boseley 2015c). The Cancer Drugs Fund was subsequently restructured due to significant overspending, which triggered another reassessment of the affordability of medicines. After another de-listing and another signature campaign-this time delivering 115,000 signatures-Roche and NICE once again agreed on an undisclosed price for Kadcyla, thus taking it out of the Cancer Drugs Fund and making it once again available as a routine treatment within the NHS. The decision acknowledged "the comments received from patients" and the signature campaigns, and argued that this experience showed that companies "can offer good deals when it comes to pricing" (NICE 2017).

This struggle over access to medicines is not confined to the UK context aloneit rather reflects a global problem that plays out slightly differently in different local (legal) contexts. Next-generation molecular medicines have become notoriously expensive, triggering discussions about drug pricing for cancer treatments on the global level (WHO 2018), within the US government (Azar 2019) and in US Congress (Facher 2019). Other cases challenging the price of medicines include for example a March-in request for the prostate cancer drug enzalutamide, brand name Xtandi (Love 2016; Knowledge Ecology International and Union for Affordable Cancer Treatment 2016; Andrew Goldman 2017), backed up by demands for a public hearing on this issue (Silverman 2016); the price of the antibody Keytruda that "was an accidental acquisition, initially ignored by Merck and almost discarded but now its main blockbuster" (Gapper 2019); and the debate of the use of Crown use provisions for the drug Orkambi for cystic fibrosis (BBC News 2019; Cystic Fibrosis Trust 2018). Price hikes of other medicines, such as Martin Shkreli's notorious $5000 \%$ price increase on Turing Pharmaceuticals' Pyrimethamine (trade name: Daraprim) (Beck 2015), or the near doubling of the price of Insulin between 2012 and 2016 in the US (Respaut and Terhune 2019), further highlighted the exclusionary power of intellectual property rights at the heart of this issue. This global problem is met by an increasingly global response. In the case of the Coalition, some of the main actors were charities and international non-governmental organisations (NGOs), which were also involved in bringing similar proceedings in the USA and in Scotland (Knowledge Ecology International and Union for Affordable Cancer Treatment 2016).

These campaigns problematise the price of medicines set by the pharmaceutical industry. Molecular biomedical research has given rise to a vast new industry, undertaking exploratory research and developing new technologies and medicines that promise personalised treatment. This industry regularly transcends national boundaries. Kadcyla was developed and is owned by Genentech (a member of the Roche Group) - an international biotech company, which manufactures a number of high profile antibodies and antivirals, and considers itself "the founder of the industry" (Genentech 2019). The antibody-drug conjugate used in Kadcyla is produced by Lonza's pharma and biotech unit, a Swiss multinational "speciality chemicals maker and life sciences group" (Reuters 2014). Lonza began working on mammalian cell cultures and monoclonal antibodies in 1996 after taking over Celltech Biologics (UK and USA), and in 2004 invested heavily in "three 20,000-L mammalian cell culture fermentation reactors in Portsmouth, NH (USA), the biggest single investment in its history" (Lonza 2019). The production of Kadcyla is located in 
this complicated geographical, legal, and institutional set up, showing the level of complexity involved in the organisation of the international biomedicine sector. This global distribution of production and an increasingly complex drug development pipeline add to high prices of final products, often including the purchase fees for start-up companies, which develop the actual treatment (Gapper 2019). This global complexity was one of the objects of the Kadcyla-challenge, as the Coalition pointed out in an online explanatory video: "at least one company has offered to manufacture a generic version of T-DM1 in England and there are at least four companies that have the capacity to make the drug for the NHS" (Love 2015).

The exclusionary power of intellectual property rights enables these production and pricing strategies to continue. They bestow a monopoly that effectively disallows other voices to influence the debate around price. The UK's concept of Crown use overrides this exclusion, as it does not require any type of license: "[t]he Crown or the government has the power to use the patent without obtaining a licence from the patentee" (Yang 2015, p. 418). In this way, the Crown use provisions are more reminiscent of the original sovereign power of the executive or monarch, which can override any other determinations, including international standards or human rights. However, in many ways the Crown use section is usually effectively equated with a compulsory license (Ibid., 416). These are relatively rare, and also likely to anger the international pharmaceutical industry, as for instance in cases of previous campaigns for compulsory licenses for HIV/AIDS treatments in South Africa and Brazil (see for example Rosenberg 2014).

The sovereignty claimed on behalf of patients in England thus invokes the potential boundlessness of sovereign rights, and makes a powerful demand for inclusion in deliberations on price and access to treatments. It also needs to be understood as a global response to a global problem involving global actors. However, conceptually the rights of the sovereign work through the power of exclusion. They represent particularist rights that can override emerging democratic initiatives in the interest of national power and executive privilege. The specific legal remedy used by the Coalition thus limits the effects of the declaration to a particular local context and has to be replicated within each legal system-making even Scotland a different locality with different effects. This draws attention to the limitations of sovereignty as a challenge to a global issue. Claims to 'genomic sovereignty' can in fact add further layers of exclusion, as shown in other declarations of sovereignty that set out to challenge the globally operating biomedical sector.

\section{Sovereign genomes}

The exclusion of any voices other than those of producers of molecular biomedicine becomes even more apparent in claims to genomic sovereignty. While the case of Kadcyla highlights the exclusionary power of drug pricing within a health system located in the global north, this challenge does not recognise the very particular context in which these cases play out. Questions of access become yet more overwhelming in context of low- and middle-income countries, but these different socio-economic contexts are rarely directly connected in analyses of either 'access 
to medicines' (Godoy 2013; t'Hoen 2009; Cassier and Correa 2014) or 'active patienthood' (Rose 2007; Heath, Rapp, and Taussig 2004; Wehling 2011). Some exceptions note the economic entanglement between these issues (Waldby and Mitchell 2006) and highlight systemic exclusions in a globally operating pharmaceutical industry (Sunder Rajan 2006).

Interpreting the Kadcyla case as a performance of molecular sovereignty connects this particular example to other sovereignty claims in the value chain of new molecular treatments. This allows comparisons between patients groups and other affective communities (Hutchison 2016) formed around experiences of exclusion by and from modern biomedicine. The Kadcyla case thus becomes part of a larger pattern of challenges to the exclusionary practices at the foundation of the global biomedical sector. But these challenges can also perpetuate exclusionary and discriminatory preconceptions, as the concept of biocoloniality (Schwartz-Marín and Restrepo 2013) shows. This article sets out how declarations of molecular sovereignties overall fail to address exclusion as a historically inscribed precondition of the intellectual property regime. Instead of counteracting the acquisitive spread of the IP system, affective communities work to further embed the notion of property over molecular life-albeit seeking to make it their own, rather than someone else's.

Claims to genomic sovereignty have emerged as one of the central responses to decades of controversial bioprospecting missions, which often resulted in accusations of biopiracy (Shiva 1998; Robinson 2010) as genetic resources were gathered in LMICs and then used as the basis for pharmaceutical 'inventions' in the Global North. To counter this unrecompensed transfer of material, the notion of some form of national sovereignty over 'indigenous' genetic resources became central to the Convention on Biological Diversity and the subsequent Nagoya Protocol, and also the centrepiece of several national legislations, for example in Mexico and Colombia (Schwartz-Marín and Restrepo 2013). The CBD's supplementary Nagoya Protocol on Access to Genetic Resources and the Fair and Equitable Sharing of Benefits Arising from their Utilization (ABS) to the Convention on Biological Diversity ('Nagoya Protocol') sought to operationalise this form of sovereignty as the basis of a new Access and Benefit Sharing (ABS) mechanism regarding non-human materials.

Genomic sovereignty thus can be a very effective device to interrupt unrecompensed transfers of materials and introduce new regulatory requirements. A 2013 report by a trilateral cooperation between WHO, WTO and WIPO on access to technologies states that " $[\mathrm{t}]$ he essential effect of the CBD and the Nagoya Protocol is to confirm national sovereignty over [genetic resources] and to establish a right of prior informed consent (PIC), approval and involvement, over the access to, and use of, associated [traditional knowledge]" (WHO, WIPO, and WTO 2013, p. 91). This challenge works in the following way: "the genetic sovereignty enacted with the $\mathrm{CBD}$ re-articulated national boundaries to the circulation of nonhuman life, thus demobilising them and banning international genetic transfer without due material transfer agreements" (Tamminen, Webster, and Vermeulen 2013, p. 213). However, Oberthür and Rosendal underline a significant disparity between intellectual property rights as part of the WTO, and the CBD's and Nagoya Protocol's status as an international agreement that is not endorsed by a number of important industrialised states: "[intellectual property rights] IPRs are guaranteed by governments and not 
touched under $\mathrm{ABS}$, while $\mathrm{ABS}$ is trying to correct the consequences by delegating to decentralized negotiations between private/public actors" (Oberthür and Rosendal 2014, p. 8).

The status and effects of intellectual property rights are thus at the centre of this debate over access and benefit sharing. The most ambitious part of negotiations leading up to the Nagoya Protocol sought to introduce a mandatory disclosure requirement into IP law, containing "the origin of genetic material as well as information to confirm that it has been acquired in accordance with [prior informed consent] and [mutually agreed terms] requirements" (Ibid., 7). This requirement sought to establish a direct link between patents and the origin of genetic material from which information has been derived-and could have fundamentally altered the minimum requirements for patentability of information derived from genetic materials. This undertaking proved too ambitious, and was not included in the final text of the Nagoya Protocol. Genetic sovereignty thus still remains an external mechanism trying to fix some of the excesses of the IP system. It has not been inscribed into the WTO's IPR system, and its relation to the WTO and the Agreement on TradeRelated Aspects of Intellectual Property Rights (TRIPS) continues to be unresolved.

The example of the WHO's Pandemic Influenza Preparedness (PIP) framework shows that a more widely recognised version of molecular sovereignty can prove a real challenge to existing international arrangements. In this case, demands for viral sovereignty (Hinterberger and Porter 2015; Elbe 2010; Fidler 2008) brought about fundamental changes in the WHO global influenza surveillance and response system for the sharing of virus samples. At the height of the bird flu pandemic in 2006, the Indonesian government decided to withhold further samples of the H5N1 strain of the virus. This was done in order to protest what the Indonesian government perceived to be "neocolonialism in global health" (Hinterberger and Porter 2015, p. 365). Indonesia's Health Minister, Siti Fadilah Supari, argued at the time:

Samples shared become the property of the WHO collaborating centres in rich countries, where they are used to generate research papers, patents and to commercialize vaccines. But the developing countries that supply the samples do not share in these benefits. In the event of a pandemic, we also risk having no access to vaccines, or having to buy them at prices we cannot afford, despite the fact that the vaccines were developed using our samples. (Butler 2007)

This move was emulated by a range of other governments and finally resulted in a renegotiating of the $\mathrm{WHO}$ framework regarding the sharing of virus samples, giving rise to a new WHO framework on Pandemic Influenza Preparedness (PIP) (WHO 2011).

This new framework directly "recognize[s] the sovereign right of States over their biological resources and the importance of collective action to mitigate public health risks" (Ibid., 4). It provides for an ABS mechanism, and its Standard Material Transfer Agreement also "prohibits those providing or receiving the virus to seek any intellectual property rights on human clinical specimens, virus isolates of pandemic potential, and modified viruses prepared from influenza viruses" (Hinterberger and Porter 2015, p. 373; see also WHO 2011, p. 31). This marked a major departure from previous arrangement and highlighted the disruptive potential of 
claims to molecular sovereignty. The sharing mechanism has thus far been judged to work well, yet its relationship with other instruments such as the Nagoya protocol remains unclear. The 2016 review of PIP went so far as to argue that such ABS agreements could prove "bad" for public health, as "numerous bilateral transactions could be required to be negotiated, which could delay the access to viruses" (WHO 2016, p. 22).

These claims to viral and genomic sovereignty clearly draw on a history of colonial exploitation, accusing the biotech sector and international organisations such as the WTO and the WHO as being complicit in neocolonialist practices. This invokes an emotional legacy of injustice, radical discrimination, and trauma, giving rise to affective communities (Hutchison 2016) of post-colonial nation states and indigenous peoples. In this context exclusion has profound racialised overtones, which for example also discredited previous bioprospecting projects such as the Stanford's Human Genome Diversity Project (HGDP) gathering human genetic materials from 'remote' tribes in the quest for the discovery of different genetic markers. Indigenous peoples referred to it as the "Vampire Project" and strongly criticised the range of chosen donor populations and the patents eventually derived from the samples (see Thacker 2005, p. 134). Similar affective communities are involved in ongoing struggles for access, as the case of the Nagoya protocol shows. But Hutchison's theorization of affect in this context also highlights the potential exclusionary effects of political communities "that are centred around the source of pain" (Hutchison 2013, p. 128). As campaigns seek to address a position of exclusion from the machinations of the globalised biotechnological and biomedical industry, they are in turn re-inscribing exclusion into their response.

\section{The biocoloniality of intellectual property}

The Coalition's legal campaign and the separate signature campaign conducted by patients seeking access to Kadcyla represent two different avenues of challenge to Roche's and NICE's decisions, showing what could be done on behalf of patients. In terms of patients' exclusion from the price setting process it is quite telling that the only thing that could be done amounted to an invocation of the rights of the crown. Similarly, the only things that could be done in the case of genomic sovereignty were several measures outside of the WTO's TRIPS agreement. Interestingly, more was done in the case of viral sovereignty, when demands were backed up with threats to withhold cooperation with virus sharing mechanisms. In spite of different outcomes, in each of these campaigns the aim was the facilitation of access to treatments for a greater number of people.

Accounts of rights claiming practices often emphasise their inclusionary effects, such as Zivi's interpretation of rights claiming as "an essential component of a robust democratic politics" (Zivi 2012, p. 14). Isin \& Nielsen (2008) and Madison (2010) also make similar arguments about the co-constitutive relation between rights claiming, rights activism, and citizenship. Zivi describes claims made by HIV/AIDS patients as demands for inclusion into the circle of those that are deemed to belong to a political community. This has a profound inclusive effect, giving rise to new 
political subjectivities that "[challenge] our understandings of who is a member of the general rights-bearing public" (Zivi 2012, p. 92). A performative perspective can thus interpret the Coalition's and excluded communities' demands as claims of belonging, reminding governments and international organisations of patients' and research subjects' important constitutive position in the delivery of healthcare.

However, as different groups invoke this form of molecular sovereignty, they are also re-asserting national boundaries in an otherwise globalised sector, with significant exclusionary effects of their own. While this may reflect the reality of national health systems that have to decide access to treatments one country at a time, the arguments used in this case not only further entrench this division, they also restate the demand for access as one of property. The exclusionary content of these interventions is somewhat reminiscent of the case of affective communities reacting to violent conflict and trauma, when "[c]ommunities become closed off, their boundaries in turn reconstituting the very disingenuous inside/outside dichotomies that help to fuel conflict in the first place" (Hutchison 2013, p. 128).

Conceptually, the use of the sovereign exception (Agamben 2005) invokes a particularist sovereign power, which does not contain unifying ambitions included for example in claims to universal human rights. The sovereign exception is inherently anti-democratic, counteracting the potential transformative power of emergent somatic rights demanding access in the name of health. In the Kadcyla case, specific challenges only applied to either England and Wales, or Scotland. Claims to genomic sovereignty also reintroduced a fractured terrain of national legislations, which then triggered complaints in the name of health, as the aforementioned critiques of the new virus sharing mechanism showed. Access to medicines and treatments are once again cast as a matter of locality, a geographical and socio-economical post-code lottery (Boseley 2015c), instead of challenging the global parameters of the price-setting and access process.

Patterns of exclusion are deeply inscribed within the historic colonial roots of the biomedical sector. Relying on the notion of biocoloniality, Schwartz-Marín and Restrepo expose an undercurrent of essentialised genetic conceptions of nationality and indigeneity contained in national legislations on genomic sovereignty (Schwartz-Marín and Restrepo 2013; for a similar critique of these essentialising effects see also Tamminen and Brown 2011). By making claims to genomic sovereignty, Mexico and Colombia ended up invoking notions of genetic uniqueness that genomic research simply does not bear out (Schwartz-Marín and Restrepo 2013). As genomic concepts travel from the laboratory to the political arena, they often become rearticulated in terms of nationality or race, further reinforcing patterns of exclusion of those that do not fit these essentialised categories. On the basis of this, Schwartz-Marín and Restrepo argue that challenges to neocolonial practices of bioprospecting paradoxically reimport racial categories that were originally created as part of a colonial view of the world.

In a similar vein, claims to sovereignty potentially pose a fundamental challenge to the IP system, but in practice further entrench the right to property over life and biodiversity — only disputing the appropriate ownership of these rights. This perpetuates the notion of individual ownership over life: the ability to isolate, describe, and then assign a monopoly over a particular molecular conception of biodiversity. The 
intellectual property system's view of nature has historically been one of terra nullius, or nobody's land, which marks out territories and biodiversity as available for conquest:

Western patent systems were designed for import monopolies, not for screening all knowledge systems to exclude existing innovations and establish prior art in other cultures. [...] Terra nullius has its contemporary equivalent in 'Bio-Nullius' - treating biodiversity knowledge as empty of prior creativity and prior rights, and hence available for 'ownership' through the claim of ‘invention'. (Shiva 2001, p. 49; emphasis in original)

Usually transferred in letters patent issued by a monarch or ruler, these privileges designated ownership over entities that were determined to be without owner. Other models of ownership, such as community ownership or traditional modes of relating to territory and nature were thus set aside and declared illegitimate. These steps can be seen as "mechanisms of appropriation" which conceptually exclude preexisting forms of knowledge, characterizing "certain natural materials that indigenous and local communities have cared for, preserved, improved, and developed as mere "wild' species" and "while the products of formal knowledge systems [...] [are being] protected as 'property', those of informal, traditional systems have been tagged the freely available "common heritage of humanity" (Roht-Arriaza 1995, p. 292). On top of this fundamental dismissal of pre-existing forms of knowledge, the exclusionary apparatus of the IP system also "works against indigenous groups primarily due to various procedural qualifications, such as the requirement of written documentation of knowledge or invention under US patent laws" (Sarma 1999, p. 116). The result is that " $[t]$ he intellectual contribution of societies and communities which have not been motivated by the objective of profit is thus exploited, but not recognized" (Shiva 1998, p. 55).

Re-drawing national boundaries through declarations of sovereignty mainly results in the re-distribution of these rights, and does not address the actual creation of them. This issue will only become more complicated with the greater availability of sophisticated innovations such as monoclonal antibodies and other treatments derived from different genetic materials. Already, as Pottage notes, biotechnology contains too many accounts of innovation and provenance, giving rise to "too much ownership" in a manner reminiscent of the "tragedy of the anticommons" (Pottage 2006 , p. 155). In response to claims to viral sovereignty, the PIP framework emphasizes access in its distribution mechanism. It stresses the need for access to virus samples in order to facilitate fast responses to potential pandemics-something that a proliferation of different ABS mechanisms could potentially prevent in a similar way to patent 'thickets'. Both the Global Initiative on Sharing All Influenza Data (GISAID) and GenBank are possible repositories of samples, which use different access procedures ensuring openness and (in GISAID's case) an identity verification process (Elbe and Buckland-Merrett 2017, p. 39). This process amounts to the granting of a license to the user, albeit an open one. While this is one of the accepted ways of ensuring access and transparency, the mechanism only deals with the question of property, and does not address the exclusion of those not deemed to be stakeholders in the PIP framework, which include “...[a]ll players-WHO, 
Member States, industry, civil society and other stakeholders" (WHO 2016, p. 5). Open licenses and the vernacular of property are not able to address pricing issues and the position of patients in this debate.

Importantly, this struggle over property between nations and industries thus does not address the perspectives of donors and patients, and avoids questions of price for medicines. Instead, challenges and agreements are made in the register of property-debating the definition of the " "proper' bounds of property" (Pottage 1998, p. 745). The Kadcyla case and ABS negotiations around the Nagoya protocol thus share (tacit) endorsement of the intellectual property regime as it stands-and work to reinforce the exclusionary system rather than to challenge it. By invoking Crown use usually granted in national emergencies, and by agreeing an arrangement that works outside of TRIPS adjusting the effects of the IP system, these challenges risk getting caught up in a process of accommodation that defuses an otherwise potentially radical contestation of the system (see also Hilberg 2015). The PIP framework's mechanism presents a different option in this regard, as it "prohibits [...] any intellectual property rights on human clinical specimens, virus isolates of pandemic potential, and modified viruses prepared from influenza viruses" (Hinterberger and Porter 2015, p. 373; see also WHO 2011, p. 31). The successful negotiation of this very specific mechanism is however already being watered down in a new global alliance for financing and coordinating the development of vaccines, the Coalition for Epidemic Preparedness Innovation (CEPI), which in December 2018 replaced a detailed equal access policy containing defined structures for IP management with a general statement about 'equitable access'. The review process moved away from a vision "reflective of the idealism that inspired the creation of CEPI" because it was found "not to be pragmatic or reflect the business realities confronted by vaccine developers"- -especially where it came to limitations to the exploitation of IP rights (Huneycutt et al. 2020, p. 2145). Amongst others, Médecins Sans Frontierès (MSF) have raised concerns about this turn towards "a vague, toothless and weak new policy" with "more detailed, but secret, implementation guidance", which threatens not to "live up to its promises to break new ground in vaccine R\&D and do things differently" (Médecins Sans Frontières 2019, p. 2). Their demand for "an unapologetic commitment to affordable access and transparency" (Ibid.) serves as a reminder of the stakes in these debates, and of the issues that claims to sovereignty simply do not address.

The coronavirus pandemic and the subsequent scramble for vaccines has once again thrown these stakes of access into stark relief, giving rise on the one hand to declarations of global solidarity as part of the WHO's COVAX facility (GAVI 2020), and on the other also to a resurgence of vaccine nationalism (Eaton 2021). In the case of vaccine nationalism, the notion of sovereignty is once again used to assert national interest and to exclude competitors in a struggle over vaccine doses between industrialised countries in the global North. In response to this, countries in the global South have been pushing for a TRIPS Waiver programme that would temporarily remove IP monopolies and thus expand opportunities for access amongst less wealthy nations (Berger 2021). The TRIPS waiver proposal has thus far however been largely resisted by industrialised countries, as once again the IP system appears untouched by crisis. Furthermore, a proposed temporary suspension 
of IP rights would not prevent their re-emergence in future, as noted for example by Lezaun and Montgomery (2015, p. 8), and even at this pressing stage of pandemic response, patent applications continue being made (Kang 2021). The question of IP rights and access thus will likely only gain in importance over the course of the pandemic, despite ongoing protestations to the contrary.

\section{Conclusions}

Claims to sovereignty can draw attention to the way in which patients, in a manner evocative of the inhabitants of terra nullius, do not get recognized as significant parts of the debate over access to expensive medicines. This article took seriously different performances of patients' sovereignty and thus was able to view them as related instantiations of a situation in which a globalised pharmaceutical industry operates in relative isolation from patients' concerns. Relying on the examples of the struggle over access to Kadcyla and the demands for recognition surrounding virus sharing mechanisms and the collection of genetic materials, the article showed how the intellectual property rights regime facilitates this division of interests, and the lengths to which patients' organisations must go in order to challenge their exclusion from questions such as price setting and access to treatments in each national context. Connecting access campaigns to other claims of molecular sovereignty, such as viral and genomic sovereignty, this allowed comparisons between groups claiming sovereignty as 'affective communities' (Hutchison 2016) formed around experiences of exclusion by and from modern biomedicine. These comparisons however also exposed the unwitting perpetuation of patterns of exclusions that are engrained in arguments of sovereignty.

Claims to molecular sovereignty do not address the continuing fiction of unclaimed biodiversity and uninhabited spaces at the heart of the intellectual property system. This biocolonial fiction diverts debate from notions of shared goods towards a struggle over assignations of property, and ends up having an anticommons effect rather than challenging the global parameters of price-setting and access to medicines. As a result, price and access continue to be at the sole discretion of the global biotechnology and pharmaceutical industry, and national health services are at best in a position of making undisclosed one-off deals. National governments are caught between the double imperatives of enabling access to medicines at reasonable costs and attracting pharmaceutical companies for instance with advantageous tax arrangements. Patients continue to be unrepresented within these settlements, and are left to contest the resulting settlements by means of signature campaigns or similar activities.

This article pointed to fundamental mechanisms of exclusion contained in both the pharmaceutical industry's price setting process, and in patients' (and populations') response to them. Its aim is to contribute to a discussion about establishing a more inclusive position on questions of price and access. A strong global response to the industry's global monopoly position could result in heightened pressure for genuine alternatives, such as prize funds and development challenges (see overview in CEWG 2012). Not that long ago, examples such as the Ebola 
crisis and the industry's pervasive failure to develop new antibiotics gave rise to renewed discussion about a global research and development fund. In order to overcome "the political constraints of individual national or regional sources of funding", a group of experts called for the establishment of "an umbrella framework for specifically funding and coordinating R\&D that not only emphasizes innovation but also secures access" (Balasegaram et al. 2015, p. 2).

The coronavirus pandemic has once again brought these divisions to the fore, recharging debates about prize funds, alternative models for funding and distribution (the WHO-led COVAX facility representing for instance an attempt at ensuring a more equitable solution to this issue), and also confronting instances of vaccine nationalism with rights-based demands for access to vaccines. A rightsbased vision of healthcare can present a fundamental challenge to a sovereigntyand property-based system, confronting price-setting mechanisms with a demand to access, which often results in a process of negotiation and compromise. This incremental ratchet-effect is part of the logic of positive human rights such as the right to health, which aims at "the highest attainable standard" of physical and mental health for example in Article 12 of the United Nation's 1966 International Covenant on Economic, Social and Cultural Rights (Hilberg 2015). The resulting process of accommodation, however, has significant governmental effects of its own, capturing more far-reaching and potentially disruptive arguments within a process of incremental adjustment. While a universalist rights-based approach thus has the power to unsettle exclusionary claims to property, it is limited in other ways-however, it can bring about openings for new settlements that for example include new ways of "tethering" (Hinterberger and Porter 2015) sources of information to entities later registered as intellectual property, as in the example of the WHO's Pandemic Influenza Preparedness (PIP) framework (set out above). These connections constitute an essential disruption to the relative isolation and abstraction of the otherwise sovereign system of property.

Previous experience from campaigns for compulsory licenses and pressure resulting in the Doha Declaration on TRIPS and Public Health (WTO 2001) show that different settlements are possible-within limits. The article's contribution seeks to challenge the existing boundaries of debate by discussing the issue of high prices for treatments in the global North in conjunction with 'access to medicines' issues usually seen as confined to the global South. This does not mean to dismiss or neglect the vast variety of lived experiences across these different localities and within them, but it rather seeks to connect different campaigns that are effectively resisting the same monopoly power exercised by a global industry. In this respect, sovereignty appears as the wrong answer to the right problem, and is shown to contribute to a further segmentation of patients' demands.

Acknowledgements The author would like to thank Stefan Elbe, the reviewers, and the participants of a workshop on Performative Rights for insightful comments and suggestions on earlier versions of this article.

\section{Declarations}

Conflict of interest The corresponding author states that there is no conflict of interest.

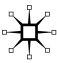




\section{References}

Agamben, Giorgio. 2005. State of Exception. Chicago: University Of Chicago Press.

Andrew Goldman. 2017. KEI, UACT Request That Trump Administration Reevaluate Xtandi Petition. Knowledge Ecology International. April 19. https://www.keionline.org/23322.

Azar, Alex. 2019. 'How Team Trump Is Bringing Drug Prices Down.' The White House. February 8. https://www.whitehouse.gov/briefings-statements/alex-azar-team-trump-bringing-drug-prices/.

BBC News. 2019. Cystic Fibrosis Drug Deadlock 'Must End,' February 4, sec. Health. https://www.bbc. com/news/health-47115039.

Balasegaram, Manica, Christian Bréchot, Jeremy Farrar, David Heymann, Nirmal Ganguly, Martin Khor, Yves Lévy, et al. 2015. A Global Biomedical R\&D Fund and Mechanism for Innovations of Public Health Importance. PLOS Medicine 12 (5): e1001831. https://doi.org/10.1371/journal.pmed.10018 31.

Beck, Julie. 2015. The Drug With a 5,000 Percent Markup. The Atlantic, September 22. http://www.theat lantic.com/health/archive/2015/09/daraprim-turing-pharmaceuticals-martin-shkreli/406546/.

Berger, Miriam. 2021. Global Vaccine Inequality Runs Deep. Some Countries Say Intellectual Property Rights Are Part of the Problem. Washington Post, February 23. https://www.washington post.com/world/2021/02/20/poor-countries-arent-getting-vaccines-waiving-intellectual-prope rty-rights-could-help/.

Boehm, Klaus, and A. Silberston. 1967. British Patent System: Volume 1, Administration.

Boseley, Sarah. 2015a. Health Secretary Urged to Tear up Patent on Breast Cancer Drug. The Guardian. October 1. http://www.theguardian.com/society/2015/oct/01/health-secretary-breast-cancer-drugnhs-kadcyla.

Boseley, Sarah. 2015b. Breast Cancer Drug Kadcyla to Remain on NHS after Manufacturer Lowers Price. The Guardian, November 4. http://www.theguardian.com/society/2015/nov/04/breast-cancerdrug-kadcyla-to-remain-on-nhs-after-manufacturer-lowers-price.

Boseley, Sarah. 2015c. Postcode Lottery for Cancer Drug as Nice Rules Kadcyla Too Expensive. The Guardian, November 17. http://www.theguardian.com/society/2015/nov/17/postcode-lottery-cancer-drug-nice-rules-kadcyla-too-expensive.

Boseley, Sarah. 2016. Big Pharma's Worst Nightmare. The Guardian, January 26. http://www.theguardian.com/society/2016/jan/26/big-pharmas-worst-nightmare.

Breast Cancer Now. 2015. Campaigners Deliver More than 42,000 Petition Signatures to Roche. October 29. http://breastcancernow.org/news-and-blogs/news/drug-pricing-campaigners-deliver-more-than42000-petition-signatures-to-roche-ahead-of-delisting-deadline.

Butler, Declan. 2007. Q\&A: Siti Fadilah Supari. Nature News 450 (7173): 1137-1137. https://doi.org/10. 1038/4501137a.

CEWG. 2012. Research and Development to Meet Health Needs in Developing Countries: Strengthening Global Financing and Coordination. WHO. http://www.who.int/phi/cewg_report/en/.

Cassier, Maurice, and Marilena Correa. 2014. Access to Medicines in Developing Countries: Ethical Demands and Moral Economy. Developing World Bioethics 14 (2): ii-viii. https://doi.org/10.1111/ dewb.12066.

Cystic Fibrosis Trust. 2018. Let's Protest for Orkambi. https://www.cysticfibrosis.org.uk/en/the work we do/campaigning hard/stopping the clock/orkambi/lets protest for orkambi.

Eaton, Lynn. 2021. Covid-19: WHO Warns against 'Vaccine Nationalism' or Face Further Virus Mutations. BMJ 372 (February). British Medical Journal Publishing Group: n292. doi:https://doi.org/10. 1136/bmj.n292.

Elbe, Stefan. 2010. Haggling over Viruses: The Downside Risks of Securitizing Infectious Disease. Health Policy and Planning 25 (6): 476-485. https://doi.org/10.1093/heapol/czq050.

Elbe, Stefan, and Gemma Buckland-Merrett. 2017. Data, Disease and Diplomacy: GISAID's Innovative Contributionto Global Health. Global Challenges 1 (January): 33-46. https://doi.org/10.1002/gch2. 1018.

Facher, Lev. 2019. Congress Wants These 7 Drug Company CEOs to Testify about Prices. STAT. February 4. https://www.statnews.com/2019/02/04/congress-wants-these-7-drug-company-ceos-to-testi fy-about-prices/.

Fidler, David P. 2008. Influenza Virus Samples, International Law, and Global Health Diplomacy. Emerging Infectious Diseases 14 (1): 88-94. https://doi.org/10.3201/eid1401.070700.

GAVI. 2020. COVAX Facility. https://www.gavi.org/covid19/covax-facility. 
Gapper, John. 2019. Keytruda Shows the High Price of Curing Cancer. Financial Times. February 13. https://www.ft.com/content/c1dacca6-2ec2-11e9-ba00-0251022932c8.

Genentech. 2019. About Us. Accessed January 29. https://www.gene.com/about-us.

Godoy, Angelina Snodgrass. 2013. Of Medicines and Markets: Intellectual Property and Human Rights in the Free Trade Era. Stanford, California: Stanford University Press.

Heath, Deborah, Rayna Rapp, and Karen-Sue Taussig. 2004. Genetic Citizenship. In A Companion to the Anthropology of Politics, by David Nugent and Joan Vincent, 152-67. Malden, MA: Blackwell Publishing.

Hilberg, Eva. 2015. Promoting Health or Securing the Market? The Right to Health and Intellectual Property between Radical Contestation and Accommodation. Third World Quarterly 36 (6): 1237-1252.

Hinterberger, Amy, and Natalie Porter. 2015. Genomic and Viral Sovereignty: Tethering the Materials of Global Biomedicine. Public Culture 27 (2 76): 361-86. https://doi.org/10.1215/08992 363-2841904.

Huneycutt, Brenda, Nicole Lurie, Sara Rotenberg, Richard Wilder, and Richard Hatchett. 2020. Finding Equipoise: CEPI Revises Its Equitable Access Policy. Vaccine 38 (9): 2144-2148. https://doi. org/10.1016/j.vaccine.2019.12.055.

Hutchison, Emma. 2013. Affective Communities as Security Communities. Critical Studies on Security 1 (1): 127-129. https://doi.org/10.1080/21624887.2013.790227.

Hutchison, Emma. 2016. Affective Communities in World Politics: Collective Emotions after Trauma. Cambridge Studies in International Relations. Cambridge: Cambridge University Press. https:// doi.org/10.1017/CBO9781316154670.

Isin, Engin F., and Greg M. Nielsen. 2008. Acts of Citizenship. London: Zed Books.

Kang, Hyo Yoon. 2021. Patent Capital in the Covid-19 Pandemic: Critical Intellectual Property Law. Critical Legal Thinking. February 9. https://criticallegalthinking.com/2021/02/09/patent-capitalin-the-covid-19-pandemic-critical-intellectual-property-law/.

Knowledge Ecology International, and Union for Affordable Cancer Treatment. 2016. Xtandi MarchIn Request Letter. Cancerunion.Org. January 14. http://cancerunion.org/files/Xtandi-March-InRequest-Letter-14Jan2016.pdf.

Lezaun, Javier, and Catherine M. Montgomery. 2015. The Pharmaceutical Commons: Sharing and Exclusion in Global Health Drug Development. Science, Technology \& Human Values 40 (1): $3-29$.

Lonza. 2019. Company History. Lonza. https://www.lonza.com/about-lonza/company-profile/compa ny-history.aspx.

Love, James. 2015. Video: Coalition for Affordable T-DM1 Crown Use Request (in UK, for Patents on Cancer Drug Kadcyla). Knowledge Ecology International. October 10. https://www.keionline. org/22903.

Love, James. 2016. Xtandi 2016 March-In Request. Knowledge Ecology International. January 14. https://www.keionline.org/22987.

Madison, D. Soyini. 2010. Acts of Activism - Human Rights as Radical Performance. Cambridge \& New York: Cambridge University Press.

Médecins Sans Frontières. 2019. Open Letter CEPI Equitable Access Policy. https://msfaccess.org/ sites/default/files/2019-03/RandD_Letter_MSFOpenLetterCEPIBoardEquitableAccess_ENG_ 2019.pdf.

NICE. 2017. Kadcyla New Deal for Breast Cancer Patients given Green Light in Final Draft Guidance. NewsArticle. NICE. June 15. https://www.nice.org.uk/news/article/kadcyla-new-deal-forbreast-cancer-patients-given-green-light-in-final-draft-guidance.

Oberthür, Sebastian, and G. Kristin Rosendal. 2014. Global Governance of Genetic Resources: Access and Benefit Sharing after the Nagoya Protocol. Abingdon: Routledge.

Pfizer Corporation v. Ministry of Health. 1965. Reports of Patent. Design and Trade Mark Cases 82 (8): 261-321. https://doi.org/10.1093/rpc/82.8.261.

Pottage, Alain. 1998. The Inscription of Life in Law: Genes, Patents, and Bio-Politics. The Modern Law Review 61 (5): 740-765.

Pottage, Alain. 2006. Too Much Ownership: Bio-Prospecting in the Age of Synthetic Biology. BioSocieties 1 (2): 137-158. https://doi.org/10.1017/S1745855206050241.

Respaut, Robin, and Chad Terhune. 2019. U.S. Insulin Costs per Patient Nearly Doubled from 2012 to 2016: Study. Reuters, January 22. https://www.reuters.com/article/us-usa-healthcare-diabetescost-idUSKCN1PG136. 
Reuters. 2014. UPDATE 2-Lonza Profit Boosted by Drug Production Outsourcing. Reuters, July 24. https://www.reuters.com/article/lonza-group-results-idUSL6NOPZ11U20140724.

Robinson, Daniel F. 2010. Confronting Biopiracy-Challenges, Cases and International Debates. London \& Washington: Earthscan.

Roht-Arriaza, Naomi. 1995. Of Seeds and Shamans: The Appropriation of the Scientific and Technical Knowledge of Indigenous and Local Communities. Michigan Journal of International Law 17: 919-965

Rose, Nikolas. 2007. Politics of Life Itself: Biomedicine, Power, and Subjectivity in the Twenty-First Century. Princeton: Princeton University Press.

Rosenberg, Stephanie T. 2014. Asserting The Primacy of Health Over Patent Rights: A Comparative Study of the Processes That Led to the Use of Compulsory Licensing in Thailand and Brazil. Developing World Bioethics 14 (2): 83-91. https://doi.org/10.1111/dewb.12050.

Sarma, Lakshmi. 1999. Biopiracy: Twentieth Century Imperialism in the Form of International Agreements. International and Comparative Law Journal 13 (1): 107-136.

Schwartz-Marín, Ernesto, and Eduardo Restrepo. 2013. Biocoloniality, Governance, and the Protection of 'Genetic Identities' in Mexico and Colombia. Sociology 47 (5): 993-1010. https://doi.org/ $10.1177 / 0038038513494506$.

Shiva, Vandana. 1998. Biopiracy: The Plunder of Nature and Knowledge. Boston, MA: South End Press.

Shiva, Vandana. 2001. Protect or Plunder?: Understanding Intellectual Property Rights. London; New York: Zed Books.

Silverman, Ed. 2016. Sanders, Other Lawmakers Seek NIH Hearing to Override Drug Patent. STAT. March 28. https://www.statnews.com/pharmalot/2016/03/28/sanders-cancer-drug-prices/.

Staines, Richard. 2017. Kadcyla Finally Gets OK after Price Cut and NICE Concessions. Pharmaphorum. June 16. https://pharmaphorum.com/news/kadcyla-set-regular-nhs-funding-nice-backing/.

Sunder Rajan, Kaushik. 2006. Biocapital: The Constitution of Postgenomic Life. Durham: Duke University Press Books.

t'Hoen, Ellen F.M. 2009. The Global Politics of Pharmaceutical Monopoly Power - Drug Patents, Access, Innovation and the Application of the WTO Doha Declaration on TRIPS and Public Health. Diemen: AMB Publishers.

Tamminen, Sakari, and Nik Brown. 2011. Nativitas: Capitalizing Genetic Nationhood. New Genetics and Society 30 (1): 73-99. https://doi.org/10.1080/14636778.2011.552301.

Tamminen, Sakari, Andrew Webster, and Niki Vermeulen. 2013. Bio-Objects: Life in the 21st Century. Ashgate Publishing, Ltd.

Thacker, Eugene. 2005. The Global Genome: Biotechnology, Politics and Culture. Cambridge, Mass.: MIT Press.

The Coalition for Affordable T-DM1. 2015. Notice of Intent to Request for Non-Exclusive Compulsory Licence on Patents to Expand Access to T-DM1. Cancerunion.Org. October 1. http://cance runion.org/files/Jeremy-Hunt-1October2015-CoalitionforAffordable-TDM1-CL.pdf.

Triggle, Nick. 2014. NHS Says No to New Breast Cancer Drug Kadcyla. BBC News. August 8. http:// www.bbc.co.uk/news/health-28688311.

WHO, WIPO, and WTO. 2013. Promoting Access to Medical Technologies and Innovation-Intersections between Public Health, Intellectual Property and Trade. http://www.wipo.int/policy/en/ global_health/trilateral_cooperation.html.

WHO. 2011. Pandemic Influenza Preparedness Framework. http://www.who.int/influenza/resources/ pip_framework/en/.

WHO. 2016. Review of the Pandemic Influenza Preparedness Framework. http://apps.who.int/gb/ ebwha/pdf_files/EB140/B140_16-en.pdf.

WHO. 2018. Technical Report: Pricing of Cancer Medicines and Its Impacts: A Comprehensive Technical Report for the World Health Assembly Resolution 70.12: Operative Paragraph 2.9 on Pricing Approaches and Their Impacts on Availability and Affordability of Medicines for the Prevention and Treatment of Cancer. Geneva: World Health Organization. https://apps.who.int/iris/ handle/10665/277190.

WTO. 2001. Declaration on the TRIPS Agreement and Public Health (WT/MIN(01)/DEC/2). Ministerial Conference, Doha. http://www.wto.org/english/thewto_e/minist_e/min01_e/mindecl_ trips_e.pdf.

Waldby, Catherine, and Robert Mitchell. 2006. Tissue Economies: Blood, Organs, and Cell Lines in Late Capitalism. Durham, N.C.: Duke University Press. 
Wehling, Peter. 2011. Biology, Citizenship and the Government of Biomedicine - Exploring the Concept of Biological Citizenship. In Governmentality: Current Issues and Future Challenges, by Ulrich Bröckling, Susanne Krasmann, and Thomas Lemke, 225-46. New York \& London: Routledge.

Yang, Celeste C. 2015. Crown Use and Government Use. In Compulsory Licensing: Practical Experiences and Ways Forward, by Reto M. Hilty and Kung-Chung Liu, 397-419. Berlin: Springer.

Zivi, Karen. 2012. Making Rights Claims-A Practice of Democratic Citizenship. Oxford: Oxford University Press.

Publisher's Note Springer Nature remains neutral with regard to jurisdictional claims in published maps and institutional affiliations.

Eva Hilberg Research Associate at the Faculty of Sociological Studies at the University of Sheffield, UK. 